\title{
Therapeutic Concentrations of Glucocorticoids Suppress the Antimicrobial Activity of Human Macrophages without Impairing Their Responsiveness to Gamma Interferon
}

\author{
Andreas Schaffner \\ Department of Medicine, University of Zürich, CH-8091 Zürich, Switzerland
}

\begin{abstract}
By exposing human blood-derived macrophages and alveolar macrophages in vitro to dexamethasone, we showed in these studies that glucocorticoids markedly suppress the antimicrobial activity of macrophages but not macrophage activation by lymphokines. As little as $2.5 \times 10^{-8} \mathrm{~mol} /$ liter of dexamethasone prevented macrophages from inhibiting germination of Aspergillus spores or from eliminating ingested bacteria such as $L$ isteria, Nocardia, or Salmonella. Damage to macrophage function was inhibited by progesterone and appeared to be receptor-mediated. In accordance with in vivo observations, dexamethasone required 24-36 $\mathrm{h}$ to suppress antimicrobial activity. While glucocorticoids interfered with base-line activity of macrophages, dexamethasone concentrations comparable to drug levels in patients had no effect on macrophage activation. Proliferating lymphocytes and $\gamma$-interferon thus increased the antimicrobial activity of phagocytes exposed to glucocorticoids over that of control cells. Macrophage activation and correction of the dexamethasone effect by $\boldsymbol{\gamma}$-interferon, however, was dependent on the pathogen. The lymphokine enhanced the antimicrobial activity of dexamethasone-treated macrophages against Listeria and Salmonella but not against Aspergillus or Nocardia. Dexamethasone-induced damage to the antimicrobial activity of human macrophages in vitro parallels observations that glucocorticoids render laboratory animals susceptible to listeriosis and aspergillosis by damaging resident macrophages. Suppression of macrophage antimicrobial activity should thus be considered when treating patients with glucocorticoids; its prevention by $\boldsymbol{\gamma}$ interferon might be beneficial for some but not all pathogens.
\end{abstract}

\section{Introduction}

Observations of patients undergoing glucocorticoid (GC) ${ }^{1}$ therapy (1-3) or suffering from Cushing's syndrome (4) have established that GC affect host resistance to a broad range of microorganisms. GC affect cell-mediated (reviewed in 5,6) and hu-

Address reprint requests to Dr. Schaffner, Medizinische Klinik, Room CH 13, University Hospital CH-8091, Zürich, Switzerland.

Received for publication 22 February 1985 and in revised form 28 May 1985.

1. Abbreviations used in this paper: $\gamma$-IFN, gamma interferon; CGD, chronic granulomatous disease; Con-A, Concanavalin A; GBSS, Gey's balanced salt solution; GC, glucocorticoid(s); PPD, purified protein derivative; PS, Penicillin-Streptomycin.

J. Clin. Invest.

(C) The American Society for Clinical Investigation, Inc. $0021-9738 / 85 / 11 / 1755 / 10 \quad \$ 1.00$

Volume 76, November 1985, 1755-1764 moral immunity (6) as well as phagocyte function (reviewed in 6 ), but the relative contribution of individual immunosuppressive mechanisms to the impairment of host defense has not been defined.

We have recently shown in mice that suppression of the antimicrobial activity of resident macrophages by cortisone is critical for induction of overwhelming infection with Aspergillus (7) and Listeria (8), two important opportunistic pathogens. The concept that GC affect the ability of the macrophage to kill ingested microorganisms, however, has not found uniform acceptance because confirmation of this GC effect on pure phagocyte preparations is lacking. In previous studies, exposure of mononuclear phagocytes to GC either had no effect $(9,10)$ on the antimicrobial activity or had an effect only at GC concentrations of $16-100 \mu \mathrm{g} / \mathrm{ml}$ (11), concentrations that exceed clinical drug levels. In humans, administration of GC in doses of 100-500 $\mathrm{mg}$ results in drug levels that do not exceed $1-2 \mu \mathrm{g} / \mathrm{ml}$ for sustained time periods $(12,13)$. Also, the peak GC level of $20 \mu \mathrm{g} /$ $\mathrm{ml}$ obtained in humans after infusion of 1-2 $\mathrm{g}$ of methylprednisolone (Upjohn Co., Kalamazoo, MI) is not comparable to a GC concentration of $16-100 \mu \mathrm{g} / \mathrm{ml}$ in cell culture medium supplemented with only $10 \%$ serum (11), since in vivo about $90 \%$ of the drug is immobilized by albumin and thus remains biologically inactive $(13,14)$. Furthermore, in patients with Cushing's syndrome, severe opportunistic infections such as aspergillosis, nocardiosis, or listeriosis occur at cortisol levels ranging from 0.4 to $1.8 \mu \mathrm{g} / \mathrm{ml}$ (4).

Hence, while animal studies $(7,8,15)$ indicate that $G C$ affect the ability of macrophages to kill ingested microorganisms, no convincing proof exists for a direct steroid effect on the antimicrobial activity of these cells. Similarly, effects of therapeutic GC levels on the process of macrophage activation by lymphokines are controversial. Studies of the activity of mouse peritoneal macrophages against Toxoplasma gondii showed that hydrocortisone succinate in a concentration of $100 \mu \mathrm{g} / \mathrm{ml}$ prevented macrophage activation by lymphokines (16). In contrast, cortisol in concentrations up to $50 \mu \mathrm{g} / \mathrm{ml}$ did not interfere with lymphokine-mediated suppression of bacterial proliferation in human alveolar macrophages and blood-derived macrophages infected with Legionella pneumophila (10). Such conflicting evidence prompted this reanalysis of the effect of GC on the antimicrobial activity of macrophages and on their responsiveness to lymphokines. By taking into account that receptor-mediated (hormonal) effects of GC may require many hours for expression (17), the present studies characterize a dramatic reduction of the antimicrobial activity of human blood-derived and alveolar macrophages by GC. Furthermore, they suggest that GC-induced damage to antimicrobial function of macrophages can be prevented or reverted for some but not for all microorganisms by $\gamma$-interferon ( $\gamma$-IFN) or proliferating lymphocytes. 


\section{Methods}

Organisms. A lot of Listeria monocytogenes strain EGD kept virulent by passages through mice was frozen in aliquots of $2 \mathrm{ml}$ at $-70^{\circ} \mathrm{C}$. Suspensions of Listeria and of single spores of $A$. fumigatus isolated from a patient with disseminated aspergillosis were prepared in Gey's balanced salt solution (GBSS) as described previously $(7,8)$. Strain GUH2 of $N$. asteroides was grown in brain heart infusion broth on a shaking platform overnight, washed three times in GBSS, homogenized with teflon pestles, and filtered through cotton gauze to give a suspension of coccoid bacteria or rods. A serum-resistant strain of Salmonella typhimurium, originally isolated from a cow, was grown overnight in trypticase soy broth. Inocula of spores and bacteria were quantitated by the pour plate technique (7) or by culturing serial dilutions on agar plates (8).

Media, serum, and reagents. Brain heart infusion, trypticase soy broth, trypticase soy agar, and Sabouraud dextrose agar were all from Difco Laboratories, Detroit, MI. Medium-199 (M-199), GBSS, and PenicillinStreptomycin (PS) were from Gibco Europe (Basel, Switzerland), dexamethasone (Sigma Chemical Co., St. Louis, MO), progesterone (Sigma Chemical Co.), and cortisol (Calbiochem-Behring Corp., La Jolla, CA) were dissolved at a concentration of $2.5 \times 10^{-2} \mathrm{~mol} / \mathrm{liter}$ in absolute ethanol and then diluted to the indicated concentrations in M-199. Hydrocortisone succinate (Upjohn Co.) was directly dissolved in M-199. Pyrogen-free human recombinant $\gamma$-IFN in frozen aliquots of $1.2 \times 10^{6}$ $\mathrm{U} / \mathrm{ml}$ in phosphate-buffered saline (PBS) was a gift from Dr. L. Gerlis (Biogen SA, Geneva, Switzerland), defrosted $\gamma$-IFN was stored at $4^{\circ} \mathrm{C}$ not longer than $4 \mathrm{~d}$. Other media supplements included Cyclosporin $\mathrm{A}$ (a gift from Dr. J. F. Borel, Sandoz, Ltd., Basel, Switzerland), purified protein derivative (PPD) from $M$. tuberculosis, Statens Serum Institut, Copenhagen, Denmark, Concanavalin A (Con A; Sigma Chemical Co.), and Tobramycin (Eli Lilly and Co., Indianapolis, IN). Serum from normal volunteers was prepared as described (18).

Mononuclear phagocytes. Blood mononuclear cells from normal volunteers and three patients with chronic granulomatous disease of childhood (courtesy of Dr. R. Seger, Children's Hospital, University of Zürich) were separated by the Ficoll-Hypaque technique and monolayers were prepared on 12-mm glass coverslips by a slight modification of the method of Nagakawara et al. (19) as fully described (18). Alveolar macrophages were obtained by lavage of the lung with $3 \times 50 \mathrm{ml}$ of saline through a wedged fiberoptic bronchoscope (courtesy of Dr. E. Russi, University Hospital, Zürich) from a normal individual, a patient with the acquired immune deficiency syndrome without pulmonary pathology, and a patient with limited lung cancer. After filtration through two layers of loose cotton gauze, the cell yield was $2-4 \times 10^{7}$ cells with $>95 \%$ viable macrophages (Trypan Blue, Giemsa). Monolayers of blood-derived macrophages and alveolar macrophages were obtained by placing 0.1 $\mathrm{ml}$ of a suspension with $1.5 \times 10^{7}$ and $3 \times 10^{6}$, respectively, of washed cells per $\mathrm{ml}$ of M-199 supplemented with $25 \%$ human serum on $12-\mathrm{mm}$ coverslips placed in 35-mm tissue culture dishes (Falcon Plastics, Oxnard, CA). After incubation for $1 \mathrm{~h}$ at $37^{\circ} \mathrm{C}$ for adhesion of mononuclear phagocytes, coverslips were washed four times with prewarmed GBSS, transferred into 16-mm diam plastic cluster plates (Falcon Plastics), and cultured in M-199 supplemented with 25\% human serum and with steroids, $\gamma$-IFN, lymphocytes, or other additives as indicated. Where appropriate, equivalent amounts of solvents were added to control wells (i.e., for steroids, ethanol was added to a final concentration of $\leq 0.1 \%$ ). Monolayers always consisted of $\geq 98 \%$ mononuclear phagocytes as determined by Giemsa stain and phagocytosis of Aspergillus spores. For experiments with Aspergillus, PS (50 U/ml and $50 \mu \mathrm{g} / \mathrm{ml})$ was added to the medium. Medium supplemented with the appropriate drugs and reagents was changed daily throughout the experiments. Secretion of lysozyme by macrophage monolayers was assayed in supernatants with Micrococcus lysodeiktiticus cell walls as substrate and compared with egg white lysozyme standards (20). Lysozyme background activity (1-2 $\mu \mathrm{g} / \mathrm{ml}$ ) of medium supplemented with $25 \%$ serum was subtracted.

Assay for the antimicrobial activity of macrophages. Suppression of germination of spores from Aspergillus ingested by macrophages was assayed $24 \mathrm{~h}$ after phagocytosis as fully described previously $(7,18)$.
Germination rates of spores are expressed as the percentage of spores forming mycelia among 200 counted per coverslip from four coverslips. The germination rate of spores incubated in medium alone was not influenced by the steroids or $\gamma$-IFN and was always $>95 \%$ at $24 \mathrm{~h}$. The antibacterial activity of macrophages was quantitated by monitoring the percentage of cells infected over time. In brief, monolayers were challenged with $2-5 \times 10^{7}$ bacteria suspended in GBSS per coverslip and incubated for $1 \mathrm{~h}$ with bacteria, washed four times by gentle rocking with prewarmed GBSS, and then further incubated in complete medium for the indicated time periods. In experiments with Listeria, if not stated otherwise, tobramycin in a bacteriostatic concentration of $1.2 \mu \mathrm{g} / \mathrm{ml}$ was added to the medium after phagocytosis, to prevent continuous infection of macrophages by extracellularly replicating bacteria. An aminoglycoside was chosen because of its minimal antimicrobial activity within phagocytes. At indicated times, the medium was aspirated, coverslips were rapidly dried in a laminar air flow, and stained by the May-GiemsaGrünwald method. The percentage of cells with intracellular bacteria was then enumerated among 800 cells from quadruplicate coverslips discriminating in addition between cells with $1-10$ and $>10$ bacteria per cell. This limit was chosen because cells always contained $<10$ bacteria immediately after phagocytosis and bacterial counts above 10 per cell thus reflected intracellular replication of bacteria.

Statistical analysis. Small differences between mean values were evaluated for statistical significance by $t$ test.

\section{Results}

Dose and time dependency of the suppressive effect of dexamethasone on the antifungal activity of macrophages. For a first series of experiments, monolayers of blood-derived and alveolar macrophages were exposed for $36 \mathrm{~h}$ to $2.5 \times 10^{-5}$ to $2.5 \times 10^{-10}$ $\mathrm{mol} / \mathrm{liter}$ of dexamethasone and then challenged with spores from Aspergillus fumigatus. The antifungal activity of the phagocytes was quantitated by enumerating the number of spores germinating and transforming into mycelia $24 \mathrm{~h}$ after phagocytosis. We have previously shown that spores not germinating within $24 \mathrm{~h}$ after phagocytosis have been killed by the macrophage while germinating spores escape growth inhibition and killing $(7,18)$. A full suppression of the antifungal activity of macrophages was seen over a wide dose range from $2.5 \times 10^{-5}$ to $2.5 \times 10^{-8} \mathrm{~mol} / \mathrm{liter}(9 \mu \mathrm{g} / \mathrm{ml}$ to $9 \mathrm{ng} / \mathrm{ml})$ of dexamethasone with an approximately $50 \%$ inhibitory effect at $2.5 \times 10^{-9} \mathrm{~mol} /$ liter (Fig. $1 A$ ). Thus, at dexamethasone concentrations well into the usual therapeutic dose range, a maximum suppressive effect was noted, which could not be further enhanced by exposure to yet higher GC concentrations. The fact that the monolayers consisted of $\geq 98 \%$ macrophages, as determined by Giesma morphology and phagocytosis of aspergillus spores, indicated that the observed GC effect was not mediated by contaminating lymphocytes. This was confirmed by demonstrating that $(a)$ substitution of culture medium by supernatant transferred daily from autologous monolayers put in culture $1 \mathrm{~d}$ earlier in dexamethasone-free medium did not modulate the GC effect, $(b)$ that alveolar macrophages from a patient with the acquired immunodeficiency syndrome without detectable lymphocytes in the cell preparation were equally susceptible to dexamethasone as were control cells (Fig. $1 A$ ), and (c) that $1 \mu \mathrm{g} / \mathrm{ml}$ of cyclosporin $\mathrm{A}$, which blocks the production of lymphokines, notably that of $\gamma$-IFN (21), had no effect on the antifungal activity. Furthermore, "young" blood-derived macrophages were as susceptible to dexamethasone as were tissue macrophages (Fig. $1 \mathrm{~A}$ ), which indicates that the effect could not be explained solely by a hormonal modulation of the differentiation of blood monocytes into tissue macrophages. 


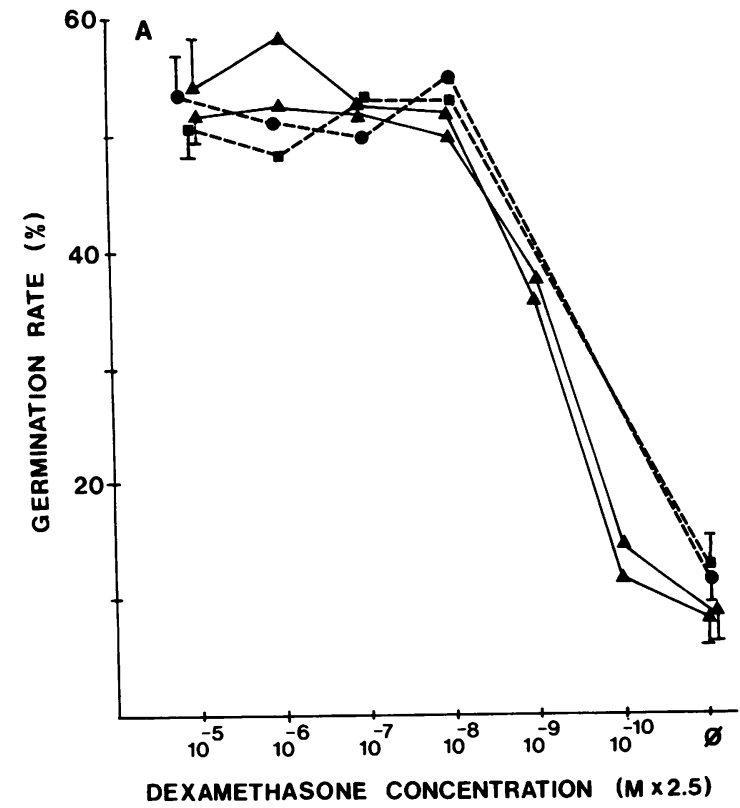

Figure $1 \mathrm{~A}$. Dose-dependent suppressive effect of dexamethasone on the activity of macrophages against Aspergillus spores. Macrophages were exposed for $36 \mathrm{~h}$ before challenge to graded concentrations of dexamethasone. Germination rates of spores $24 \mathrm{~h}$ after phagocytosis by blood-derived (-) and alveolar (---) macrophages are given from four independent experiments. Each data point represents the mean value from quadruplicate wells from an independent experiment; SD is given for the highest dexamethasone concentration and the ethanol control. Alveolar macrophages were from a normal individual $(\bullet)$ and a patient with the acquired immune deficiency syndrome (a).

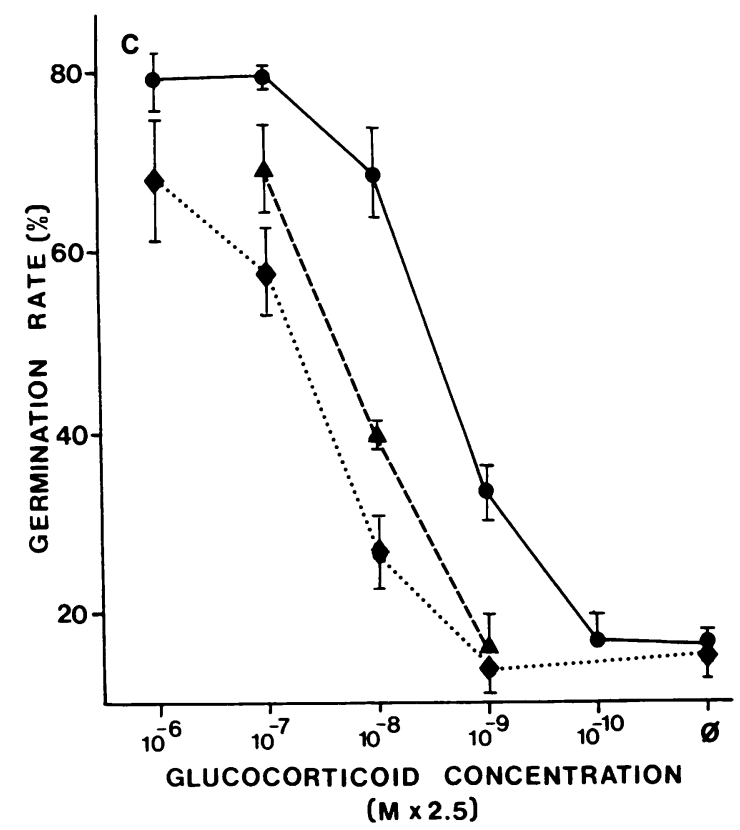

Figure $1 \mathrm{C}$. Suppression of the antifungal activity of macrophages is receptor-mediated. Glucocorticoid antagonism by progesterone and relation of the suppressive potency of dexamethasone and cortisol. Germination rates of spores $24 \mathrm{~h}$ after phagocytosis by blood-derived macrophages cultured for $36 \mathrm{~h}$ in the presence of variable dexamethasone concentrations $(\bullet)$, in the presence of $2.5 \times 10^{-5} \mathrm{~mol} / \mathrm{liter}$ of progesterone plus dexamethasone ( $\bullet$ ), or cortisol ( $₫)$. Mean \pm SD from quadruplicate wells from one representative experiment out of three.

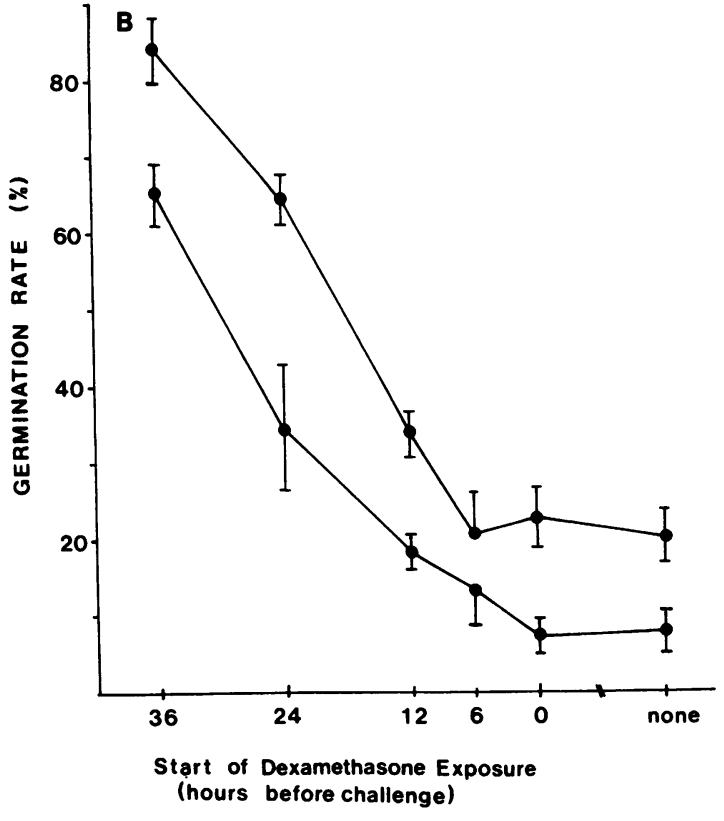

Figure 1 B. Time course of the suppressive effect of dexamethasone on the antifungal activity of macrophages. Blood-derived macrophages were exposed to $2.5 \times 10^{-7} \mathrm{~mol} / \mathrm{liter}$ of dexamethasone for variable time periods before challenge with spores. Each data point represents the mean value of the germination rate \pm SD from quadruplicate wells; results from two independent experiments.

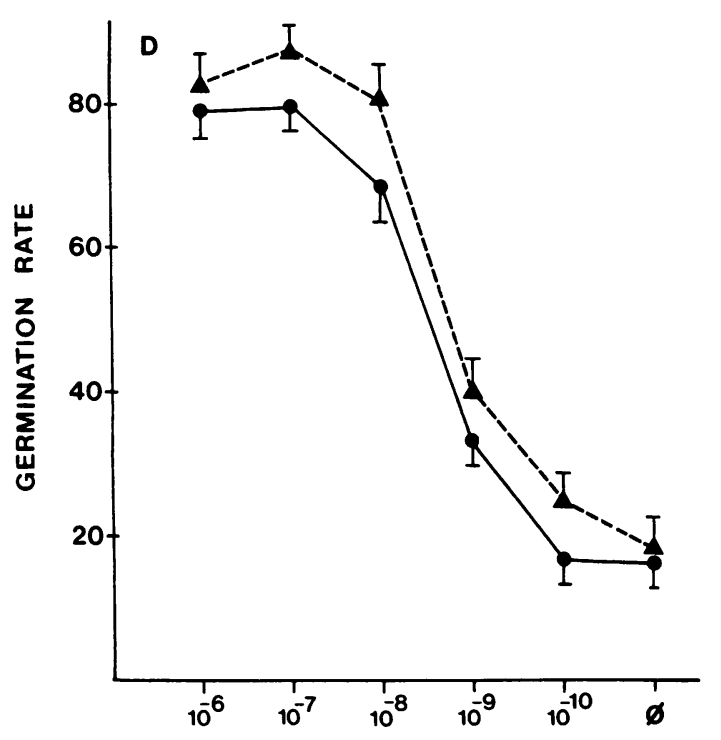

DEXAMETHASONE CONCENTRATION $(M \times 2.5)$

Figure $1 \mathrm{D}$. The dexamethasone effect on the antifungal activity of blood-derived macrophages does not depend on oxidative killing mechanisms. The antifungal activity of macrophages from a normal individual (๑) and from a patient with chronic granulomatous disease of childhood $(\Delta)$ were compared after culture of phagocytes in the presence of variable dexamethasone concentrations for $36 \mathrm{~h}$. Mean \pm SD of germination rates of spores $24 \mathrm{~h}$ after phagocytosis from quadruplicate wells. 
A 36-h time period was initially selected for incubation with GC based on our previous finding in experimental aspergillosis that mice had to be given cortisone acetate at least $36 \mathrm{~h}$ before challenge to achieve a maximum suppression of the sporicidal activity of macrophages (7). Accordingly, an assessment of the time dependency of the dexamethasone effect on the antifungal activity of macrophages in vitro indicated that only a steroid exposure for $24 \mathrm{~h}$ or longer resulted in a significant reduction of the antifungal activity (Fig. $1 B$ ). The effect was maximal at $36 \mathrm{~h}$, 'since exposure to $2.5 \times 10^{-7} \mathrm{~mol} / \mathrm{liter}$ of dexamethasone for up to $84 \mathrm{~h}$ did not further increase the germination rate of ingested spores (germination after $36 \mathrm{~h}$ of dexamethasone: $86 \pm 4 \%$ compared with $84 \pm 3 \%$ after $84 \mathrm{~h}, P>0.05$ ).

Demonstration that the suppressive effect of glucocorticoids is receptor-mediated. The observation that the maximum suppression of the antifungal activity of macrophages occurred at dexamethasone concentrations as low as $2.5 \times 10^{-8} \mathrm{~mol} / \mathrm{liter}$ indicated that the effect was mediated by cytoplasmic high-affinity receptors for steroids. This was confirmed by showing that a 10-1,000-fold excess of progesterone, which is an antagonist of GC at the receptor $(17,22)$, progressively inhibited the effect of dexamethasone. Progesterone itself had no effect on the antifungal activity of macrophages (Fig. $1 C$ ) and did not influence the germination rate of spores incubated in medium alone (data not shown). Furthermore, when the suppressive effect of dexamethasone was compared with that of cortisol, cortisol turned out to be $\sim 10$ times less potent than dexamethasone (Fig. 1C), as expected for a receptor-mediated GC effect in vitro (22).

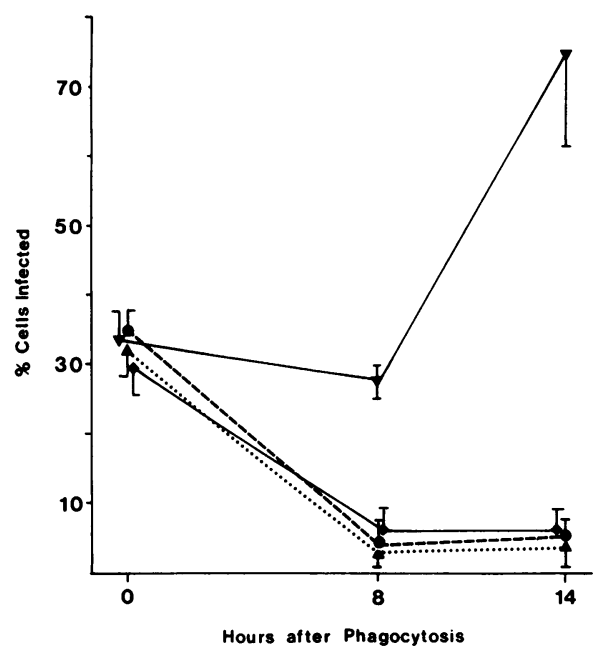

Figure 2. Destruction of Listeria monocytogenes phagocytized by blood-derived macrophages. The percentage of blood-derived macrophages with cell-associated bacteria was enumerated immediately after incubation for phagocytosis and removal of noningested bacteria by washing and after eight and $14 \mathrm{~h}$ of incubation, respectively. ( $)$, control cells; $(\nabla)$, cells exposed for $36 \mathrm{~h}$ before phagocytosis to $2.5 \times 10^{-7}$ $\mathrm{mol} /$ liter of dexamethasone; (•), cells exposed for $36 \mathrm{~h}$ to $48 \mathrm{U} / \mathrm{ml}$ of $\gamma$-IFN; ( $\Delta)$, cells exposed for $36 \mathrm{~h}$ simultaneously to a combination of $2.5 \times 10^{-7} \mathrm{~mol} /$ liter of dexamethasone and $48 \mathrm{U} / \mathrm{ml}$ of $\gamma$-IFN. There were no significant differences in phagocytosis between the different cell preparations $(P>0.05$ for differences of the percent of cells infected at $0 \mathrm{~h}$; comparable number of bacteria [0-4] per cell). At $8 \mathrm{~h}$, $11 \pm 1 \%$ of dexamethasone-exposed cells harbored $>10$ bacteria/cell compared with $0 \%$ in all other groups and at $14 \mathrm{~h}$ this difference widened to $48.5 \%$ vs. $0-1.25 \%$. Mean \pm SD of the percentage of cells with visible bacteria from quadruplicate wells from one of two comparable experiments.

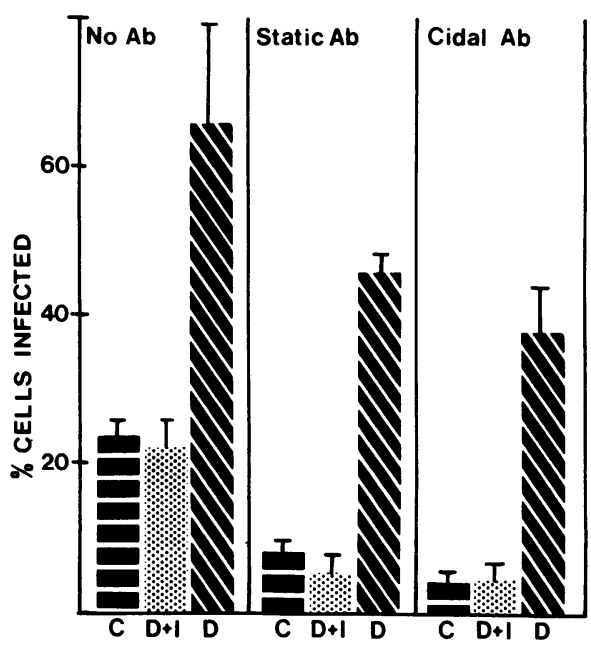

Figure 3. Comparison of the effect of various aminoglycoside concentrations on the antibacterial activity of macrophages. After challenge of macrophages with Listeria and removal of noningested bacteria from monolayers by washing, no antibiotic (no Ab), a bacteriostatic concentration of $1.2 \mu \mathrm{g} / \mathrm{ml}$ (static $\mathrm{Ab}$ ), or a bactericidal concentration of $10 \mu \mathrm{g} / \mathrm{ml}$ of Tobramycin (cidal Ab) was added to the medium. The antibiotic prevented extracellular multiplication of bacteria and continuous infection during incubation without altering the relation between the antimicrobial activity of control cells $(C)$, cells treated with dexamethasone (D), or a combination of dexamethasone and $\gamma$-IFN $(\mathrm{D}+\mathrm{I})$. Macrophages were exposed for $36 \mathrm{~h}$ to $2.5 \times 10^{-7} \mathrm{M}$ of dexamethasone and to $48 \mathrm{U} / \mathrm{ml}$ of $\gamma$-IFN. The height of the columns represents the mean value \pm SD of cells infected after incubation for $8 \mathrm{~h}$ after phagocytosis from quadruplicate wells from one representative experiment out of two comparable experiments. The infection rate of cells immediately after removal of noningested bacteria was $52.5 \%$ with no significant difference among different cell preparations.

Exclusion of nonspecific toxicity of glucocorticoids. Neither cortisol nor dexamethasone in a concentration up to $2.5 \times 10^{-5}$ $\mathrm{mol} /$ liter affected the cell density of the monolayers as judged by phase contrast microscopy. Cell viability was $>96 \%$ after all regimens as determined in several experiments immediately after challenge by Trypan Blue exclusion. There was no difference between the phagocytic index of glucocorticoid treated or control cells in experiments with spores (not shown) or subsequent experiments with bacteria (Figs. 2 and 8), indicating preserved phagocytic function after dexamethasone or cortisol exposure. To further exclude nonspecific toxicity, we studied the effects of GC on anabolic function in two experiments with bloodderived macrophages. Lysozyme was selected as marker, because synthesis and secretion of this enzyme has been found to be independent from GC-modulation (22). Monolayers cultured in medium with $2.5 \times 10^{-6}, 2.5 \times 10^{-7}$, or $2.5 \times 10^{-8} \mathrm{~mol} / \mathrm{liter}$ of dexamethasone for $48 \mathrm{~h}$ secreted in the continuous presence of the steroid $6.6 \pm 0.5,6.8 \pm 0.4$, and $6.6 \pm 0.5 \mu \mathrm{g}$ of lysozyme per coverslip within the next $18 \mathrm{~h}$ (mean $\pm \mathrm{SD}$ from quadruplicate wells) compared with $6.8 \pm 0.6 \mu \mathrm{g} /$ coverslip secreted by control cells $(P>0.05$ for all differences). Comparable results were obtained with monolayers exposed to cortisol in concentrations up to $2.5 \times 10^{-5} \mathrm{~mol} /$ liter (not shown).

Suppression of the activity of macrophages against spores by dexamethasone is independent from oxidative killing systems. We have previously shown that inhibition and killing of spores from Aspergilli by macrophages is independent from oxidative killing mechanisms (18). By comparing the activity of macro- 


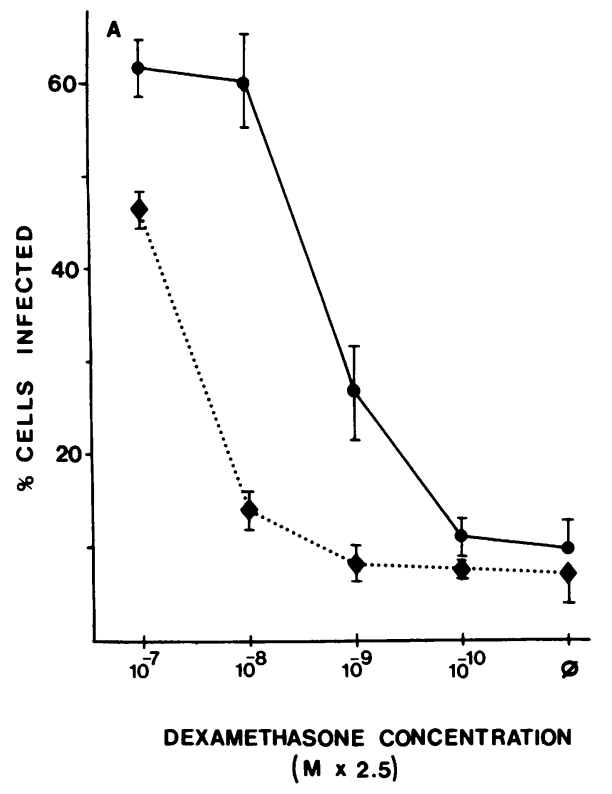

Figure $4 \mathrm{~A}$. Dose dependent suppressive effect of dexamethasone on the antilisterial activity of macrophages and antagonism of the glucocorticoid effect by progesterone. Blood-derived macrophages were exposed for $36 \mathrm{~h}$ before challenge to graded concentrations of dexamethasone in the presence $(\bullet)$ or absence $(\bullet)$ of $2.5 \times 10^{-5} \mathrm{~mol} /$ liter of progesterone. The percentage of cells infected immediately after removal of noningested bacteria was uniform at all dexamethasone and/or progesterone concentrations and was $67.5 \%$ with $0-5$ bacteria/cell.

Mean \pm SD of the percent of cells harboring bacteria $8 \mathrm{~h}$ after phagocytosis from one of two comparable experiments.

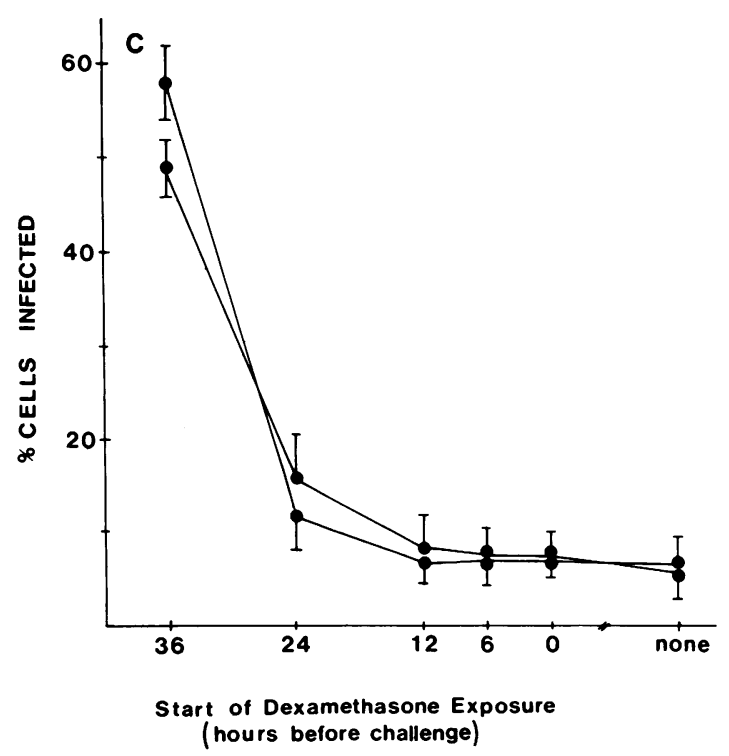

Figure $4 C$. Time course of the effect of dexamethasone on the antilisterial activity of blood-derived macrophages. Relation of the percent of cells unable to clear ingested bacteria to the duration of exposure to $2.5 \times 10^{-7} \mathrm{~mol} /$ liter of dexamethasone. Each point represents the mean $\pm \mathrm{SD}$ of the percent cells infected $8 \mathrm{~h}$ after phagocytosis from quadruplicate wells from two independent experiments. Immediately after removal of noningested bacteria, 58\% (experiment 1 ) and $61.5 \%$ (experiment 2), respectively, of cells were associated with Listeria (0$4 /$ cell).

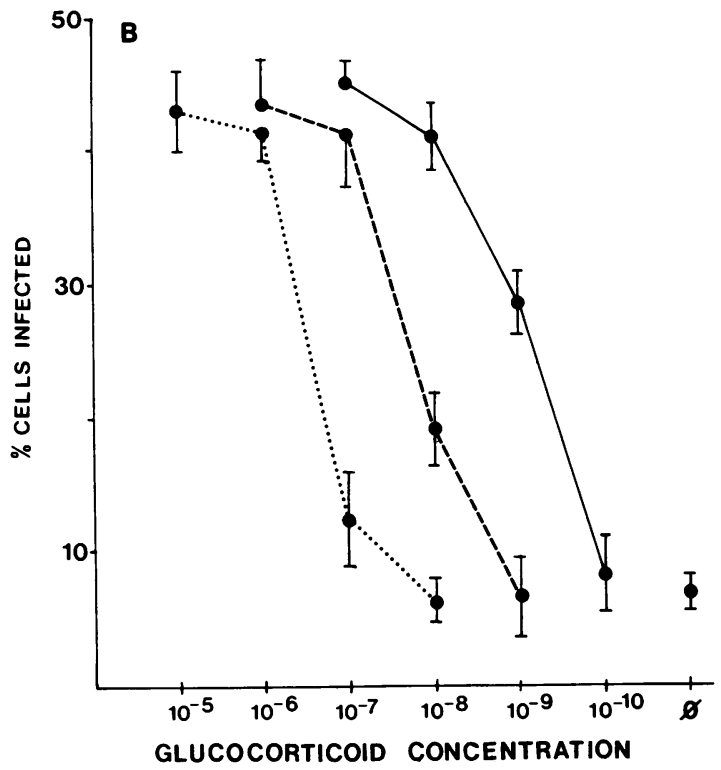

$(M \times 2.5)$

Figure 4 B. Comparison of the relative potency of dexamethasone, cortisol, and hydrocortisone succinate to suppress the antilisterial activity of blood-derived macrophages. Monolayers were exposed for 36 $\mathrm{h}$ before challenge with Listeria to graded concentrations of dexa-

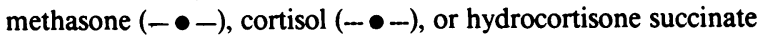
$(\ldots \bullet \ldots)$. For this comparison, ethanol, the solvent for cortisol and dexamethasone, was added in the appropriate concentrations to cultures with hydrocortisone succinate, which was directly diluted in the medium. Comparable results were obtained in a second experiment in which ethanol was omitted (not shown). Mean \pm SD of the percentage of cells remaining infected $8 \mathrm{~h}$ after challenge from quadruplicate wells from one of two comparable experiments.

phages from normal volunteers with that of cells from patients with chronic granulomatous disease which are unable to mount a respiratory burst, we found that both kinds of cells were equally effective in inhibiting the fungus and equally susceptible to the effects of dexamethasone (Fig. $1 D$ ). These results were confirmed with blood-derived macrophages from two additional chronic granulomatous disease (CGD) patients. Exposure of blood-derived macrophages from a second individual with CGD to $2.5 \times 10^{-7} \mathrm{M}$ of dexamethasone for $36 \mathrm{~h}$ increased the germination rate of ingested spores $4.6 \pm 0.4$-fold (mean \pm SD of increase from quadruplicate wells) over that of spores ingested by CGD control cells, compared with an increase of the germination rate of 5.2 \pm 0.3 -fold for spores ingested by cells from a normal donor). Cortisol in a concentration of $2.5 \times 10^{-6} \mathrm{~mol} / \mathrm{liter}$ had a comparable effect (not shown). Similar results were obtained with cells from a third individual with CGD with a 4.9 \pm 0.2 -fold increase of the germination rate after $36 \mathrm{~h}$ exposure to the same hormone concentration (compared with 5.2 \pm 0.3 -fold increase with cells from a normal donor studied in parallel; $P>0.05$ for all comparisons between CGD and control cells).

Effect of dexamethasone on the antilisterial activity of macrophages. To investigate whether GC affect the antibacterial activity of macrophages comparably to the activity against Aspergillus spores, we next studied the effects of dexamethasone on the antilisterial activity of macrophages. Listeria monocytogenes was selected because previous studies in mice indicated that damage to the antimicrobial activity of resident macrophages by $\mathrm{GC}$ is a critical immunosuppressive mechanism in listeriosis 
(8). First, a model was developed in which the antilisterial activity of macrophages could be assessed morphologically by enumerating the percentage of cells harboring bacteria over time. This was possible since normally bacteria disappeared from $70-80 \%$ of blood-derived macrophages within $8 \mathrm{~h}$ (Fig. 2). Bacteria disappeared from phagocytes by destruction and digestion since the number of bacteria did not increase in the supernatant ( $<2 \times 10^{2}$ bacteria/ml at each time point). There was also no selective loss of infected cells to the supernatant during incubation because cells were not detectable in cytospin preparations from the supernatant. $8 \mathrm{~h}$ after challenge with bacteria, infected cells were randomly distributed over the monolayer. Thereafter, clusters of infected cells arose around individual macrophages overwhelmed by intracellularly multiplying bacteria in dexamethasone-treated monolayers, resulting in a rapid increase of the number of cells harboring bacteria (Fig. 2). Thus, while the number of cells remaining infected after an incubation period of $8 \mathrm{~h}$ reflected the activity of macrophages against the initial inoculum, the number of cells being infected at $14 \mathrm{~h}$ was also influenced by infection of additional cells during the experiment in dexamethasone-treated monolayers. Therefore, in all subsequent experiments we chose an incubation time of $8 \mathrm{~h}$ after challenge, for evaluation of the antilisterial activity of macrophages. By this time the effects of regimens for modulation of macrophage function (studied in detail below) appeared to be fully developed (Fig. 2). To prevent continuous infection of macrophages by extracellularly multiplying bacteria during incubation, we routinely added a bacteriostatic concentration of tobramycin $(1.2 \mu \mathrm{g} / \mathrm{ml})$ to the cultures after we washed off bacteria not ingested by cells. The possibility that the addition of the antibiotic distorted the results of a comparison of the antilisterial activity of differently treated macrophage preparations was excluded (Fig. 3).

The effect of dexamethasone on the antilisterial activity of macrophages was dose-dependent and inhibited by progesterone in a manner comparable to that in the Aspergillus model (Fig. $4 \mathrm{~A}$ ). As with Aspergillus, cortisol seemed to be about 10 times less potent than dexamethasone. Furthermore, the potency of hydrocortisone succinate was investigated in the Listeria model to permit comparison with previous reports in which this steroid was studied $(9,11)$. Not unexpectedly, cortisol was more potent compared with the synthetic derivative because esterification of the hydroxy group of cortisol at position $\mathrm{C} 21$ reduces affinity to the GC receptor (23). However, the observed 10-fold difference in the potency of the two hydrocortisone compounds (Fig. $4 \mathrm{~B}$ ) could not account for the 175-fold difference between the 16 $\mu \mathrm{g} / \mathrm{ml}$ of hydrocortisone succinate needed for suppression of macrophage antimicrobial activity in one of the cited studies (11) and the present finding that $90 \mathrm{ng}$ of cortisol fully suppressed antilisterial activity of macrophages. Studies of the time course of the GC effect on the antilisterial activity again showed that prolonged incubation of macrophages with GC was necessary to achieve a suppressive effect at pharmacological hormone levels (Fig. $4 C$ ). Because macrophages were only exposed for a few hours to GC in studies with suprapharmacological concentrations of hydrocortisone succinate (11), differences in the duration of GC exposure appear even more important than the kind of hydrocortisone used to explain the impressive difference between GC concentrations required for damage of macrophage activity in this and the cited study (11).

The Listeria system apparently required an additional $12 \mathrm{~h}$ to develop a full dexamethasone effect (Fig. $4 C$ ) when compared with the fungus system (Fig. $1 B$ ). This difference, however, was most likely due to the different assay techniques used. While germination of Aspergillus spores was quantitated $24 \mathrm{~h}$ after phagocytosis, cells infected with Listeria were enumerated $8 \mathrm{~h}$ after infection of macrophages, allowing for a more extended contact with the GC in experiments involving spores.

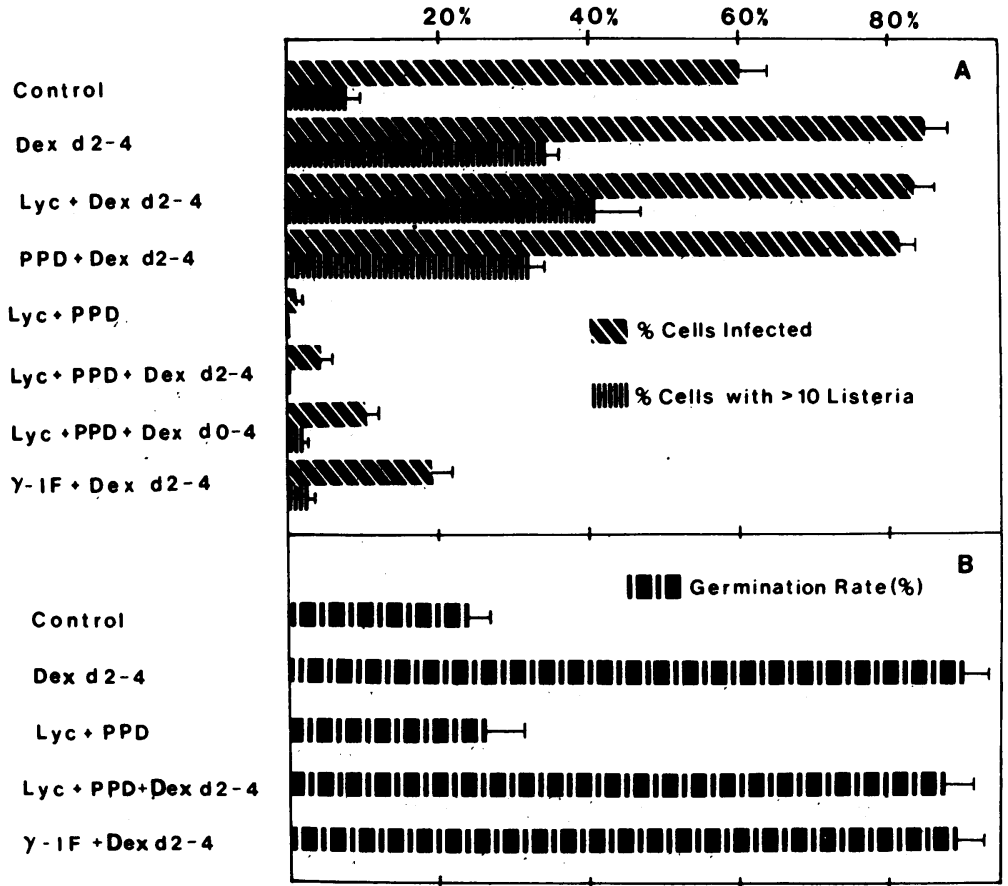

Figure 5. Effect of dexamethasone on the antifungal and antibacterial activity of blood-derived macrophages after in vitro culture for $4 \mathrm{~d}$ in the presence of proliferating lymphocytes. $(A)$ percentage of macrophages infected with $L$. monocytogenes $8 \mathrm{~h}$ after challenge; the infection rate after removal of noningested bacteria was $91-96 \%$ with 0 8 bacteria/cell. (B) Germination rate of Aspergillus spores $24 \mathrm{~h}$ after phagocytosis by macrophages. Control, monolayers cultured for $4 \mathrm{~d}$ before challenge in control medium. Dex d2-4, monolayers cultured for $2 \mathrm{~d}$ in control medium and then for $2 \mathrm{~d}$ before challenge in medium supplemented with dexamethasone. Lyc + Dex d2-4, monolayers of macrophages to which lymphocytes were replenished were cultured for $2 \mathrm{~d}$ in control medium and then for $2 \mathrm{~d}$ in the presence of dexamethasone. PPD + Dex d2-4, monolayers cultured for $2 \mathrm{~d}$ in the presence of PPD and then for $2 \mathrm{~d}$ before challenge with PPD and dexamethasone. Lyc + PPD, lymphocyte-replenished monolayers cultured for $4 \mathrm{~d}$ in the presence of PPD. Lyc + PPD + Dex d2-4, lymphocyte-replenished monolayers cultured in the presence of PPD for $2 \mathrm{~d}$ and then for $2 \mathrm{~d}$ before challenge with a combination of dexamethasone and PPD. Lyc + PPD + Dex d0-4, to lymphocyte-replenished monolayers dexamethasone was added and $2 \mathrm{~h}$ later, PPD. Cells were then cultured with these supplements for $4 \mathrm{~d}$ before challenge. $\gamma$-IF + Dex

d2-4, monolayers cultured in the presence of $\gamma$-IFN and dexamethasone for $4 \mathrm{~d}$ before challenge. The concentrations were: $2.5 \times 10^{-7} \mathrm{M}$ for dexamethasone, $50 \mu \mathrm{g} / \mathrm{ml}$ for PPD, $48 \mathrm{U} / \mathrm{ml}$ for $\gamma$-IFN, and $2 \times 10^{6}$ autologous lymphocytes per milliliter from a PPD-sensitized donor. Soluble additives were replaced with each medium change (day $0,1,2,3$, and 4). Each bar represents the mean \pm SD from quadruplicate wells from one representative experiment out of three. 
Influence of macrophage activation by proliferating lymphocytes or $\gamma$-interferon on the immunosuppressive effect of dexamethasone. The effect of dexamethasone on macrophages was studied in the presence of proliferating lymphocytes stimulated either by a recall antigen or by Con A. When macrophages and stimulated lymphocytes were cocultured for $48 \mathrm{~h}$ and then exposed to dexamethasone, the GC could no longer suppress antilisterial activity of the phagocytes below that of control cells (Fig. 5). Furthermore, when the GC was added to monolayers cocultured with PPD-sensitized lymphocytes $2 \mathrm{~h}$ before the stimulating antigen, macrophages cultured for $4 \mathrm{~d}$ under these conditions before challenge, still acquired GC resistance and eliminated bacteria much more efficiently than untreated control cells (Fig. 5). The observed macrophage activation occurred in spite of a suppressed (but not completely abolished) proliferation of lymphoblasts in the presence of the GC (compared with control wells). Comparable results were obtained when in several similar experiments the effects of PPD-sensitized lymphocytes stimulated with PPD were compared with the effects of lymphocytes stimulated with Con A (data not shown).

Since $\gamma$-IFN has been recognized as an important macrophage-activating factor produced by $\mathrm{T}$ lymphocytes (24-26), we did a series of experiments in which human recombinant $\gamma$-IFN replaced proliferating lymphocytes. $\gamma$-IFN could replace proliferating lymphocytes in rendering macrophages completely resistant to the suppressive effect of dexamethasone. Furthermore, dexamethasone at a concentration 100 times higher than that required to fully suppress antilisterial activity of "resting" macrophages did not interfere with macrophage activation by $\gamma$-IFN (Fig. $6 \mathrm{~A}$ ). Challenge of macrophages with higher numbers of bacteria resulted in heavy infection of individual cells during phagocytosis, and under these conditions even cells not exposed to GC had difficulties controlling intracellular bacteria. In contrast, the majority of heavily bacteria-laden macrophages activated by $\gamma$-IFN destroyed all intracellular bacteria. Under these conditions dexamethasone also did not interfere with the activation except at a very low $\gamma$-IFN concentration below a fully activating dose (Fig. 7).

When the time course of reversion of the dexamethasone effect on macrophages by $\gamma$-IFN was studied, it became apparent that $\gamma$-IFN affected macrophage function much more rapidly than dexamethasone, because addition of $\gamma$-IFN only $2 \mathrm{~h}$ before phagocytosis resulted in a nearly complete restitution of the antilisterial activity of GC-treated macrophages (Fig. $6 \mathrm{~B}$ ) compared with $36 \mathrm{~h}$ of exposure required to produce dexamethasone damage (Fig. $4 \mathrm{C}$ ). In addition, these experiments confirmed that even after prolonged exposure of macrophages to therapeutic dexamethasone levels, the phagocytes still responded to $\gamma$-IFN by rapid restoration of the antilisterial activity (Fig. $6 B$ ).

In contrast to the observations with Listeria, $\gamma$-IFN in concentrations of $10-100 \mathrm{U} / \mathrm{ml}$ and proliferating lymphocytes neither prevented nor reverted the deleterious effect of dexamethasone on the activity of blood-derived or alveolar macrophages against Aspergillus spores (Figs. 5 and 7). Also, higher $\gamma$-IFN concentrations up to $10^{4} \mathrm{U} / \mathrm{ml}$ were without effect on the antifungal activity of macrophages (not shown). The finding that $\gamma$-IFN corrects only for the suppressive effect of GC on macrophage activity for certain microorganisms was confirmed with Salmonella typhimurium and Nocardia asteroides. These organisms were selected because of their opportunism in patients undergoing glucocorticoid therapy, because of their ability to parasitize macrophages, and because of possible differences in their susceptibility to killing by phagocytes. While $\gamma$-IFN cor-

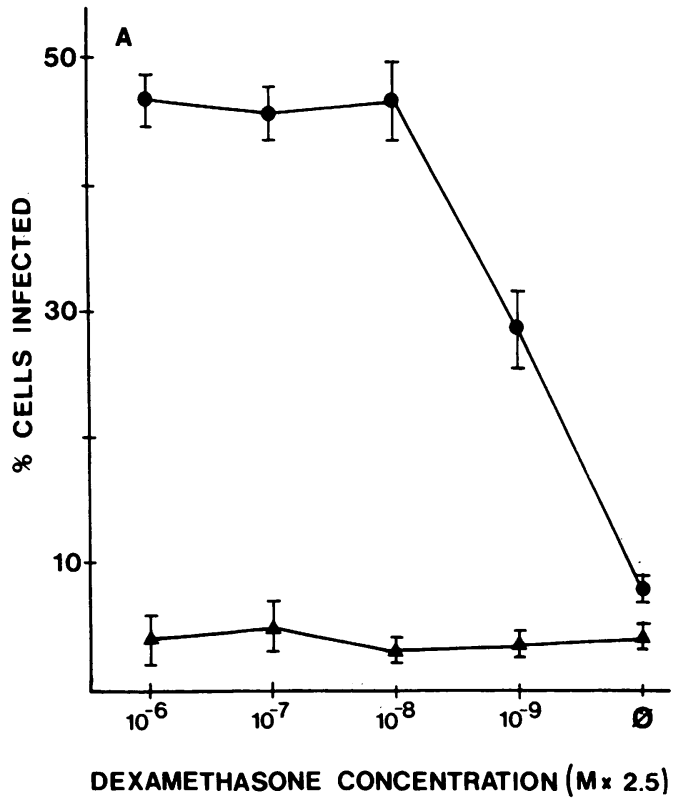

Figure $6 \mathrm{~A}$. Prevention by $\gamma$-IFN of the suppressive effect of dexamethasone on the antilisterial activity of macrophages. Blood-derived macrophages were exposed for $36 \mathrm{~h}$ to graded doses of dexamethasone in the presence ( $\Delta$ ) or absence ( $\bullet$ ) of $20 \mathrm{U} / \mathrm{ml}$ of $\gamma$-IFN. Immediately after removal of noningested bacteria $61 \%$ of cells were infected $(0-4$ bacteria/cell). Mean \pm SD of the percent of cells remaining infected from quadruplicate wells from one of two comparable experiments.

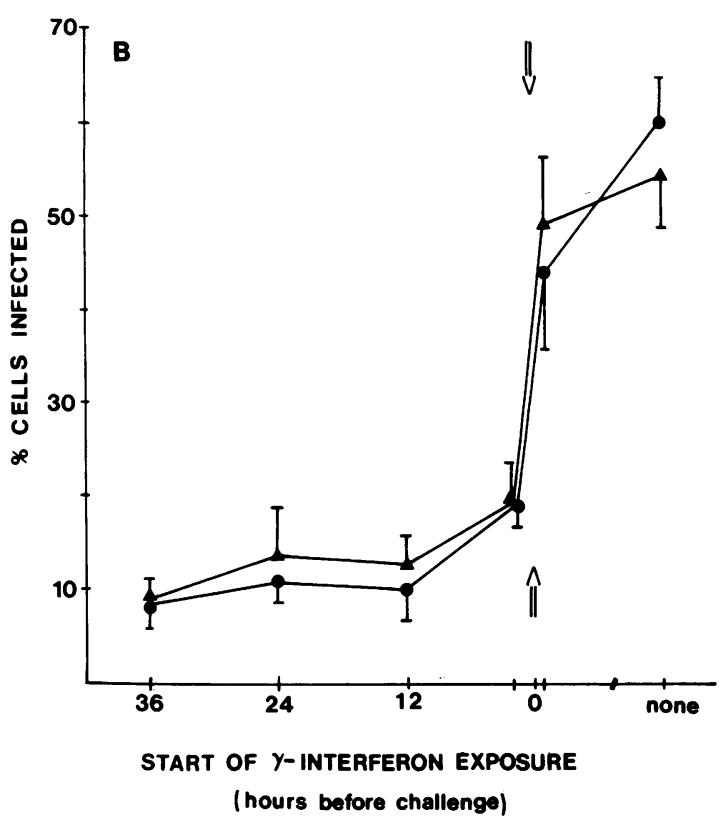

Figure 6 B. Time course of the $\gamma$-IFN effect on dexamethasone damaged macrophages in the Listeria system. To macrophages exposed for $36 \mathrm{~h}$ to $2.5 \times 10^{-7} \mathrm{M}$ of dexamethasone $48 \mathrm{U} / \mathrm{ml}$ of $\gamma$-IFN were added at various time intervals before challenge (arrow) or immediately after challenge. Each point represents the mean \pm SD of the percent of cells infected with Listeria $8 \mathrm{~h}$ after phagocytosis from quadruplicate wells of an independent experiment. The infection rate of the cells was $53 \pm 3 \%$ and $51 \pm 2 \%$ (mean \pm SD) immediately after removal of noningested bacteria with no significant difference for cells exposed for various time periods to $\gamma$-IFN. The percent of macrophages exposed neither to $\gamma$-IFN nor to dexamethasone remaining infected with bacteria $8 \mathrm{~h}$ after phagocytosis was $6.5 \pm 2 \%$ and $7 \pm 2 \%$, respectively. 


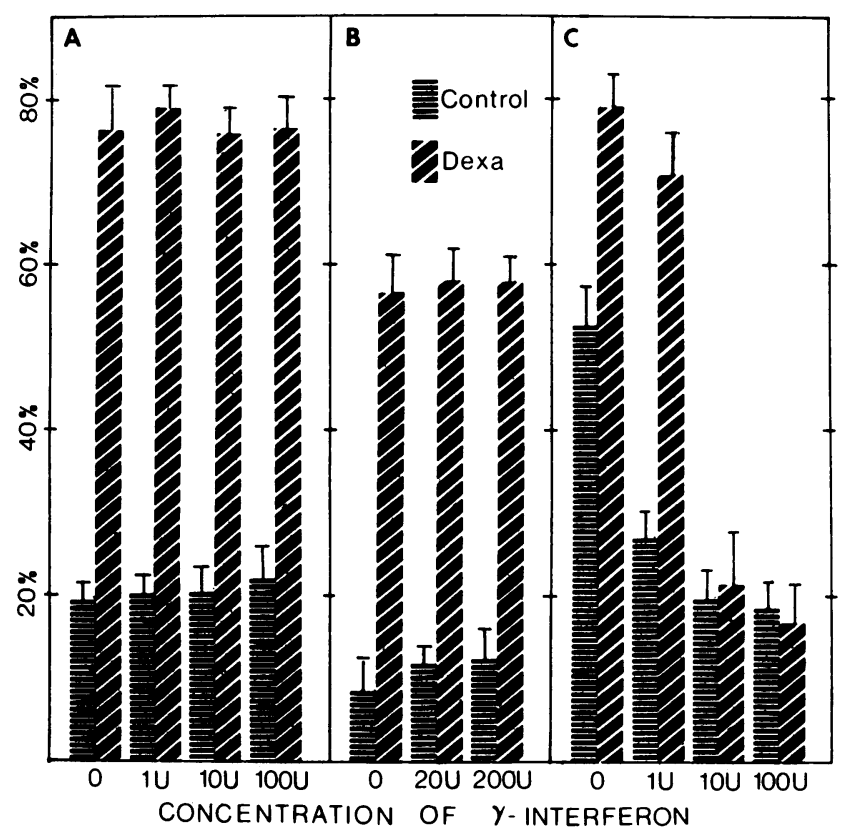

Figure 7. Failure of $\gamma$-IFN to modulate the activity of dexamethasonetreated or normal macrophages against spores from $A$. fumigatus. Macrophages were cultured for $36 \mathrm{~h}$ in the presence (Dexa) or absence (Control) of $2.5 \times 10^{-7} \mathrm{~mol} / \mathrm{liter}$ of dexamethasone and were simultaneously exposed to graded doses of $\gamma$-IFN. $(A)$ Germination rate of spores ingested by blood-derived macrophages. $(B)$ Germination rate of spores ingested by alveolar macrophages. $(C)$ Percent blood-derived macrophages remaining infected $8 \mathrm{~h}$ after ingestion of $L$. monocytogenes ( $91-96 \%$ cells initially infected with $0-10$ bacteria). Results from quadruplicate wells from one experiment with alveolar macrophages and from one representative experiment out of three with blood-derived macrophages.

rected for the glucocorticoid damage in the Salmonella model, $48 \mathrm{U} / \mathrm{ml}$ of $\gamma$-IFN did not prevent glucocorticoid damage in the Nocardia model (Fig. 8). Comparable results were obtained when the experiment was repeated with even higher concentrations of $\gamma$-IFN. Thus, $\gamma$-IFN in concentrations up to $120 \mathrm{U} / \mathrm{ml}$ did not affect the completely suppressed elimination of Nocardia but again restored in parallel studies with cells from the same donor elimination of Salmonella by dexamethasone-treated cells to a rate comparable to that in untreated control cells (data not shown).

\section{Discussion}

The present study characterizes in vitro a deleterious effect of therapeutic glucocorticoid concentrations on the ability of macrophages to kill ingested microorganisms. The results prove in pure in vitro systems direct damage by pharmacological glucocorticoid levels to the antimicrobial activity of mononuclear phagocytes, an effect found to be critical in several models of opportunistic infections $(7,8,15)$.

When macrophages were exposed for 24-36 h to GC, the antifungal and antibacterial activity of the phagocytes was fully suppressed by as little as $10 \mathrm{ng} / \mathrm{ml}$ of dexamethasone and 100 $\mathrm{ng} / \mathrm{ml}$ of cortisol with no greater effect of GC concentrations up to $10 \mu \mathrm{g} / \mathrm{ml}$. These GC concentrations are clearly in the therapeutic range. On one hand, physiological plasma cortisol levels range from 8 to $220 \mathrm{ng} / \mathrm{ml}$ during the diurnal cycle (27) with a biologically available (14) concentration of free cortisol of 0.8 $28 \mathrm{ng} / \mathrm{ml}$ (27). On the other hand, GC therapy results in sustained plasma drug levels of $1-2 \mu \mathrm{g} / \mathrm{ml}$ with as much as 100 to $500 \mathrm{ng}$ unbound hormone $(12,13)$.

Suppression of the antimicrobial activity appeared to be mediated by high-affinity GC-receptors of macrophages (20) not only because of the very low GC concentrations required for a fully suppressive effect but also because an excess of progesterone, an antagonist of GC at the receptor $(17,20,22)$, suppressed the effect of dexamethasone in a dose-dependent manner. The failure of previous studies $(9,11)$ to confirm a direct effect of therapeutic GC concentrations on the antimicrobial activity of macrophages in vitro might in part reflect the short duration of these experiments precluding an expression of receptor-mediated effects of steroids that involve synthesis of messenger RNA and proteins (28). Furthermore, the use of synthetic steroids might have influenced the glucocorticoid concentration required for a suppression of antimicrobial activity as indicated by the observation that hydrocortisone succinate, which was used by some investigators $(9,11)$, was in our hands about 10 times less potent than cortisol. Finally, the kind of microorganism studied by different authors also has to be considered to explain disparate results. Thus, Nash et al. (10) studied the effects of cortisol on the anti-Legionella activity of human blood-derived and alveolar macrophages. In this system "resting" mononuclear phagocytes do not display anti-Legionella activity; rather, the phagocytes are required to support bacterial growth. It is therefore not surprising that no suppressive effect of glucocorticoids on the antimicrobial activity of resting macrophages was noted in this model.

The observation that macrophages had to be exposed to GC for at least $24 \mathrm{~h}$ before being functionally affected raises the question of whether the steroid merely interfered with a nonphysiologic process of in vitro differentiation or in vitro functional modulation during culture. The findings that alveolar macrophages are as susceptible to corticosteroids as blood-de-

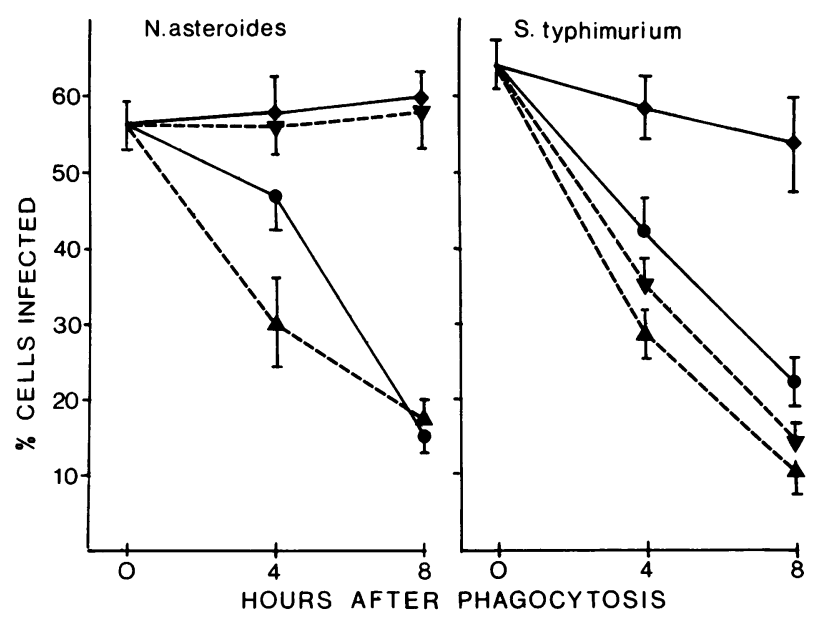

Figure 8. Confirmation that $\gamma$-IFN corrects the immunosuppressive effect of dexamethasone only for certain pathogens. Blood-derived macrophages were exposed for $36 \mathrm{~h}$ before challenge with Nocardia asteroides or Salmonella typhimurium to $2.5 \times 10^{-7} \mathrm{~mol} / \mathrm{liter}$ of dexamethasone ( $\bullet), 2.5 \times 10^{-7} \mathrm{~mol} / \mathrm{liter}$ of dexamethasone combined with

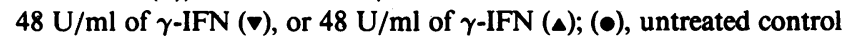
cells. Each point represents the mean \pm SD of the percent of cells infected from quadruplicate wells from one of two comparable experiments. 
rived macrophages, that blood monocytes and alveolar macrophages have the same activity against Aspergillus whether challenged with the fungus at the beginning of in vitro culture or 2 $\mathrm{d}$ later, and finally that phagocytes cultured in vitro for $2 \mathrm{~d}$ before GC exposure remain equally dexamethasone-susceptible, are against these possibilities. Likewise, damage to the antimicrobial activity of mononuclear phagocytes from laboratory animals $(7,8,15)$ and humans $(29)$ has also only been shown after GC administration for more than $24 \mathrm{~h}$.

The observation that macrophages from patients with CGD, which are unable to generate important amounts of reactive oxygen intermediates, were as sensitive to the effect of corticosteroids as were normal cells, points to killing mechanisms other than oxidative systems as targets for the corticosteroid effect. From the studies of Werb (22) it is known that GC concentrations comparable to those used here have important catabolic effects on macrophages such as reduction of the synthesis of neutral proteases. Since most, if not all, receptor-mediated GC effects are related to a modulation of protein synthesis (28), it seems likely that the effect of corticosteroids on the antimicrobial activity of macrophages similarly reflects the suppression of synthesis of proteins of the antimicrobial armature of the phagocyte. Accordingly, the time lag between the beginning of the corticoid exposure and expression of the killing defect could indicate that such suppressed proteins have to be exhausted to a critical level through protein turnover.

Contrary to previous observations on effects of excessive concentrations of hydrocortisone succinate on the in vitro responsiveness of macrophages to lymphokines (16), dexamethasone at therapeutic levels did not affect macrophage activation. This finding is in accord with the recent observation of Nash et al. (10) that cortisol does not affect lymphokine-mediated activation of human macrophages against $L$. pneumophila. In our studies on Listeria, $\gamma$-IFN abolished the steroid effect within a few hours and induced an antilisterial activity of macrophages exposed to a broad range of dexamethasone concentrations which was superior to that of untreated control cells. Thus, $\gamma$-IFN in contrast to progesterone appeared to override and not to antagonize the immunosuppressive effect of dexamethasone on macrophages, possibly by affecting other killing mechanisms than those damaged by GC. This concept is supported by the observation that $\gamma$-IFN, which seems to enhance oxidative killing (26), had in contrast to experiments with Listeria or Salmonella no effect on the base-line activity of macrophages against $\mathrm{As}$ pergillus spores, which apparently are not killed by oxidative mechanisms (18). $\gamma$-IFN similarly did not affect the complete loss of the bactericidal activity of dexamethasone-treated phagocytes against Nocardia, an organism which, like Aspergillus spores but unlike Listeria and Salmonella, is resistant to killing by neutrophil granulocytes $(7,30)$. Based on these observations, one might speculate that by damaging nonoxidative killing mechanisms, dexamethasone affects antimicrobial activity of "resting" macrophages against a broad range of microorganisms, and that activation of oxidative killing systems by $\gamma$-IFN might be sufficient for some but not all microorganisms to correct for the GC-damage. This hypothesis is supported by the recent observations of Mokoena and Gordon (31), which indicate that dexamethasone suppresses lymphokine-induced expression of several markers of macrophage activation but has no effect on lymphokine-induced enhancement of the respiratory burst.

This pathogen-dependent dichotomy in the opposing effects of $\gamma$-IFN and GC on the antimicrobial activity of macrophages might explain why in a model of listeriosis (32) but not in models of aspergillosis (7), mice can be rendered cortisone-resistant by prior immunization. The failure of $\gamma$-IFN to correct for the immunosuppressive effect of GC on the antimicrobial activity of macrophages against some microorganisms hampers somewhat the enthusiastic outlook (21) for the possibility of multiple simultaneous immunomodulatory interventions such as an immunosuppression with corticosteroids and a simultaneous protection from opportunistic infections with recombinant $\gamma$-IFN.

Dexamethasone added to cocultures of proliferating lymphocytes and macrophages did not prevent activation of the phagocyte against Listeria. Thus, in this in vitro model which depends on a mitogen or on a recall antigen for induction of lymphoproliferation, the afferent limb of cell-mediated immunity appeared less susceptible to therapeutic GC concentrations than the effector limb, the macrophage. However, extrapolation to the in vivo situation is hampered by other effects of corticosteroids on cell-mediated immunity such as recruitment of lymphocytes or antigen access (6), which are not reflected in the model. Furthermore, it is likely that there are important differences between a secondary and a primary immune response that cannot be studied in vitro. Nevertheless, our previous comparison of the effects of cortisone on listeriosis and aspergillosis in genetically athymic and normal mice suggests that the macrophage is also in vivo the critical target for the immunosuppressive effect of glucocorticoids in these infections $(7,8)$.

\section{Acknowledgments}

I wish to thank Dr. R. Zinkernagel for the EGD strain of Listeria monocytogenes; Dr. G. A. Felice for the GUH-2 strain of Nocardia asteroides, and Biogen SA, Geneva, Switzerland for supplying r-Interferon gamma. I also thank Dr. R. Keller and Dr. T. Schaffner for their critical and encouraging discussions, Eva End and Ursula Schärer for technical assistance, and $\mathrm{R}$. Shack for preparing the manuscript.

This investigation was supported by grant 3.815.0.83 from the Swiss National Science Foundation and the EMDO Foundation.

\section{References}

1. Ginzler, E., H. Diamond, D. Kaplan, M. Weiner, M. Schlesinger, and M. Seleznick. 1978. Computer analysis of factors influencing frequency of infection in systemic lupus erythematosus. Arthritis Rheum. 21:37-44.

2. Anderson, R. J., L. A. Schaffer, D. B. Olin, and T. C. Eickhoff. 1973. Infectious risk factors in the immunosuppressed host. Am. J. Med. $54: 453-460$.

3. Gustafson, T. L., W. Schaffner, G. B. Lavely, C. W. Stratton, H. K. Johnson, and R. H. Hutcherson, Jr. 1983. Invasie aspergillosis in renal transplant recipients: correlation with corticosteroid therapy. $J$. Infect. Dis. 148:230-238.

4. Graham, S., and W. S. Tucker. 1984. Opportunistic infections in endogenous Cushing's syndrome. Ann. Intern. Med. 101:334-338.

5. Crabtree, G. R., S. Gillis, K. A. Smith, and A. Munck. 1979. Glucocorticoids and immune responses. Arthritis Rheum. 22:1246-1256.

6. Fauci, A. S. 1979. Immunosuppressive and anti-inflammatory effects of glucocorticoids. In Glucocorticoid Hormone Action. J. D. Baxter and G. G. Rousseau, editors. Springer Publishing Co., Inc., Berlin/Heidelberg/New York. 449-465.

7. Schaffner, A., H. Douglas, and A. Braude. 1982. Selective protection against conidia by mononuclear and against mycelia by polymorphonuclear phagocytes in resistance to Aspergillus. J. Clin. Invest. 69:617631.

8. Schaffner, A., H. Douglas, and C. E. Davis. 1983. Models of T 
cell deficiency in listeriosis: the effects of cortisone and cyclosporin A on normal and nude BALB/c mice. J. Immunol. 131:450-453.

9. Van Zweit, T. L., J. Thompson, and R. Van Furth. 1975. Effect of glucocorticosteroids on the phagocytosis and intracellular killing by peritoneal macrophages. Infect. Immun. 12:699-705.

10. Nash, T. W., D. M. Libby, and M. A. Horwitz. 1984. Interaction between Legionaires' disease bacterium (Legionella pneumophila) and human alveolar macrophages. Influence of antibody, lymphokines, and hydrocortisone. J. Clin. Invest. 74:771-782.

11. Rinehart, J. J., S. P. Balcerzak, A. L. Sagone, and A. F. Lo Buglio. 1974. Effects of corticosteroids on human monocyte function. J. Clin. Invest. 54:1337-1343.

12. Peterson, R. E., S. L. Wyngaarden, S. L. Guerra, B. B. Brodie, and B. B. Bunim. 1955. The physiologic deposition and metabolic rate of hydrocortisone in man. J. Clin. Invest. 34:1779-1794.

13. Webel, M. L., R. E. Ritts, Jr., H. F. Taswell, J. V. Donadio, Jr., and J. E. Woods. 1974. Cellular immunity after intravenous administration of methylprenisolone. J. Lab. Clin. Med. 83:383-392.

14. Ballard, P. L. 1979. Delivery and transport of glucocorticoids to target cells. In Glucocorticoid Hormone Action. J. D. Baxter and G. G. Rousseau, editors. Springer Publishing Co., Inc., Berlin/Heidelberg/New York. 25-48.

15. Blackwood, L. L., and J. E. Pennington. 1982. Dose-dependent effect of glucocorticosteroids on pulmonary defense in a steroid resistant host. Am. Rev. Respir. Dis. 126:1045-1049.

16. Masur, H., H. W. Murray, and T. C. Jones. 1982. Effect of hydrocortisone on macrophage response to lymphokine. Infect. Immun. 35:709-714.

17. Munck, A., and K. Leung. 1977. Glucocorticoid receptors and mechanisms of action. In Receptors and Mechanism of Action of Steroid Hormones, Part II. Pasqualini, J. R., editor. Marcel Dekker, Inc., New York.

18. Schaffner, A., H. Douglas, A. I. Braude, and C. E. Davis. 1983. Killing of aspergillus spores depends on the anatomical souce of the macrophage. Infect. Immun. 2:1109-1115.

19. Nagakawara, A., C. F. Nathan, and Z. A. Cohn. 1981. Hydrogen peroxide metabolism in human monocytes during differentiation in vitro. J. Clin. Invest. 68:1243-1252.

20. Werb, Z., R. Foley, and A. Munck. 1978. Interaction of gluco- corticoids with macrophages. Identification of glucocorticoid receptors in monocytes and macrophages. J. Exp: Med. 147:1684-1694.

21. Reem, G. H., and N. H. Yeh. 1984. Interleukin 2 regulates expression of its receptor and synthesis of gamma interferon by human T lymphocytes. Science (Wash. DC). 225:429-430.

22. Werb, Z. 1978. Biochemical actions of glucocorticoids on macrophages in culture. Specific inhibition of elastase collagenase, and plasminogen activator secretion and effects on other metabolic functions. $J$. Exp. Med. 147:1695-1723.

23. Ponec, M. 1982. Glucocorticoids and cultured human skin cells: specific intracellular binding and structure-activity relationship. $\mathrm{Br}$. $J$. Dermatol. 107(Suppl. 23):24-29.

24. Celada, A., P. W. Gray, E. Rinderknecht, and R. D. Schreiber. 1984. Evidence for a gamma-interferon receptor that regulates macrophage tumoricidal activity. J. Exp. Med. 160:55-74.

25. Schultz, R. M., and W. J. Kleinschmidt. 1983. Functional identity between murine gamma-interferon and macrophage activating factor. Nature (Lond.). 305:239-240.

26. Nathan, C. F., H. W. Murray, M. E. Weibe, and B. Y. Rubin. 1983. Identification of interferon-gamma as the lymphokine that activates human macrophage oxidative metabolism and antimicrobial activity. $J$. Exp. Med. 158:670-689.

27. Baumann, G., G. Rappaport, T. Lemarchand-Beraud, and J. P. Felber. 1975. Free cortisol index: a rapid and simple estimation of free cortisol in human plasma. J. Clin. Endocrinol. Metab. 40:462-469.

28. O'Malley, B. W. 1984. Steroid hormone action in eucaryotic cells. J. Clin. Invest. 74:307-312.

29. Rinehart, J. J., A. L. Sagone, S. P. Balcerzak, G. A. Ackermann, and A. F. LoBuglio. 1975. Effects of corticosteroid therapy on human monocyte function. N. Engl. J. Med. 292:236-241.

30. Felice, G. A., B. L. Beaman, J. A. Krick, and J. Remington. 1980. Effects of human neutrophils and monocytes on Nocardia asteroides: failure of killing despite occurrence of the oxidative metabolic burst. $J$. Infect. Dis. 142:432-438.

31. Mokoena, T., and S. Gordon. 1985. Human macrophage activation. Modulation of mannosyl, fucosyl receptor activity in vitro by lymphokines, gamma and alpha interferons, and dexamethasone. J. Clin. Invest. 75:624-631.

32. North, R. J. 1971. The action of cortisone acetate on cell-mediated immunity to infection. J. Exp. Med. 134:1485-1500. 